\title{
31. NERITIC EARLY EOCENE SMALLER FORAMINIFERA FROM THE KŌKO SEAMOUNT (EMPEROR SEAMOUNTS, CENTRAL NORTHERN PACIFIC)
}

\author{
Jorge Ferrer, Esso Production Research-European, 33321 Bègles (France)
}

\section{INTRODUCTION}

Site 308 of Leg 32 of the Deep Sea Drilling Project is located on the western slope of the flat-topped Köko Seamount of the Emperor Seamount chain at $34^{\circ} 58.94^{\prime} \mathrm{N}, 172^{\circ} 08.98^{\prime} \mathrm{E}$, in a water depth of 1331 meters. The penetration below sea floor is 68.5 meters of which 30.5 meters were cored with a $24 \%$ recovery.

The sediments consist of altered volcanic ash and biogenous volcanic silt or, more rarely, sand. A description of the lithology and other details can be found in the Site Report chapter, this volume.

Almost all washed residues from Site 308 contain abundant smaller benthonic foraminifera, ostracodes, fragments of corals, and bryozoans. In addition, molds of small gastropods and fragments of pelecypods are frequently observed.

The rare planktonic foraminifera found in Cores 1, 2, 3 , and at the top of Core 4 indicate the early Eocene Globorotalia formosa formosa Zone, whereas coccoliths in Cores 1 and 2 are characteristic of the early Eocene Discoaster lodoensis Zone (Luterbacher, this volume; Bukry, this volume).

The benthonic foraminiferal assemblages and the benthonic/planktonic ratio of these deposits clearly indicate an inner shelf environment where sporadical communication with the open ocean existed.

Although the paleoecology of the Paleogene is not very well known, the recent work by Ferrer et al. (1973) indicates a way to apply our knowledge of the ecology of the Recent foraminifera to extinct genera and species. In that publication, the presence of abundant Discorbis, Valvulina, Valvulineria, Pararotalia, and Heterolepa, together with scarce planktonic foraminifera, suggest a maximum water depth of 50 to 60 meters. The presence of abundant Lamarckina and common Remanellina in the Pacific sediments probably indicates a difference in water temperature and turbulence.

As to the stratigraphic and geographic distribution of these microfossils, the genera Valvulina, Clavulina, and Glabratella had not previously been mentioned from the Pacific Eocene. Their stratigraphic distribution agrees roughly with their range in other geographic areas (mainly western Europe and the United States). Also Remanellina sp. has been recorded for the first time from the Pacific, and it seems to occur stratigraphically earlier than originally stated by Tappan and Loeblich (1968).

The distribution of the foraminiferal species is given in Figure 1. The most abundant and conspicuous species are discussed briefly and illustrated on Plates 1 to 6 .

The assemblages of benthonic foraminifera are in general dominated by calcareous species, but in a few

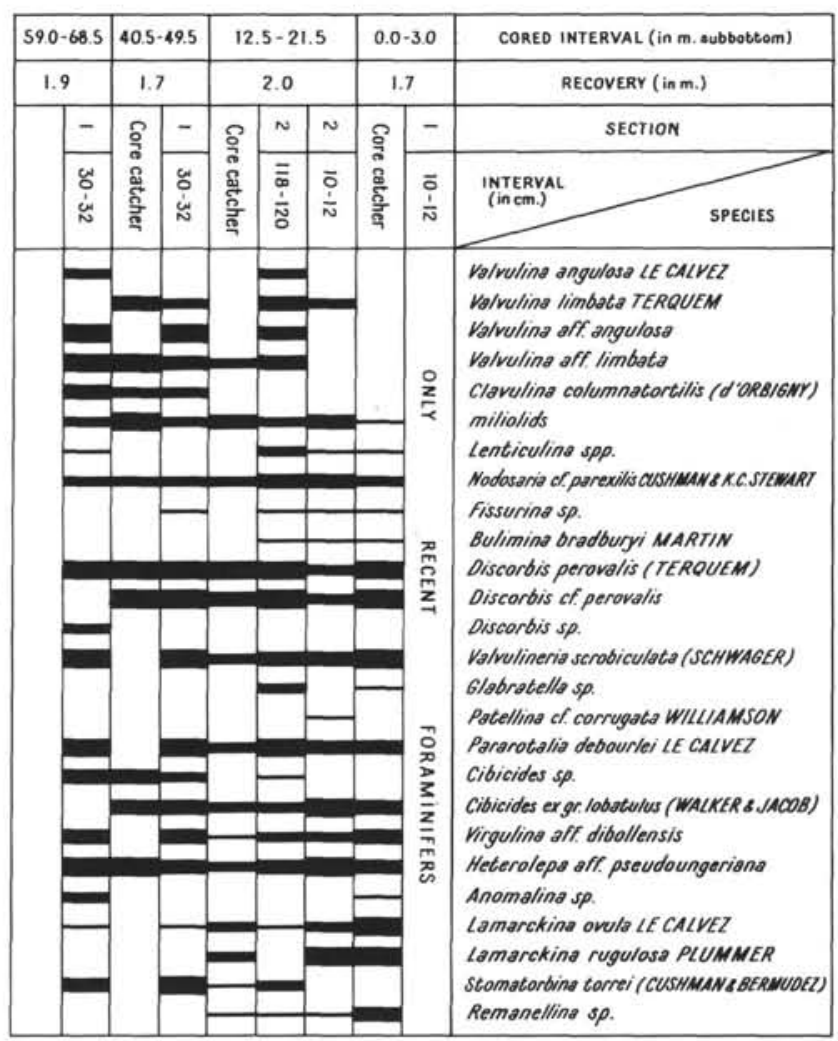

Figure 1. Distribution of benthonic foraminifera at Site 308.

samples arenaceous species may represent up to $20 \%$ of the foraminiferal assemblage (Figure 1).

The general aspect of the foraminiferal faunas is strikingly similar to age-corresponding neritic assemblages from western Europe (e.g., southern Pyrenees, Ferrer et al., 1973). The composition of the foraminiferal fauna indicates a nearshore environment with normal salinity.

The ostracodes, examined by H. J. Oertli (Appendix A), represent a rich nearshore assemblage which warrants a detailed investigation. Although not of the same specific composition, the general aspect of the ostracode fauna is similar to the one described by Hazel and Holden (1971) from the upper Eocene of Tonga. Some of the more prominent species are illustrated on Plates 7 and 8 which were kindly prepared by $\mathrm{H}$. J. Oertli.

The bryozoa from Site 308 (A. H. Cheetham, this volume) suggest that the depositional depth could not have been much less than 60 meters. 


\section{TAXONOMIC NOTES ON SOME SPECIES}

\section{Genus VALVULINA d'Orbigny, 1826}

Valvulina angulosa Le Calvez, 1952

(Plate 1, Figures 2, 8)

V. angulosa Y. Le Calvez, 1952, p. 12, 13, pl. 1, fig. 3. Y. Le Calvez, 1970, p. 21, 22, fig. 1. Ferrer et al., 1973, p. 24, pl. 1, fig. 4; pl. 6, fig. 1,4

Although only a few specimens are present in the samples studied, I think that the Le Calvez species is well represented in the Pacific. Its most characteristic feature is the rather small, pointed initial part followed by the large angular final chambers. This is the first time that the genus Valvulina has been mentioned from the early Eocene of the Pacific. (Cushman described $V$. chapmani 1936 from the Miocene of Oamaru, New Zealand.)

\section{Valvulina sp. aff. V. angulosa Le Calvez, 1952} (Plate 1, Figures 3, 9, 10)

This species is more abundant than the typical $V$. angulosa. It differs from the species of Le Calvez by its larger initial part and less angular final chambers, which make it distinguishable from $V$. angulosa although they look similar. In fact it may be just a geographic variety of $V$. angulosa.

\section{Valvulina limbata Terquem, 1882}

(Plate 1, Figures 5, 7)

V. limbata Terquem, 1882, p. 102, pl. 11, fig. 7. Y. Le Calvez, 1970, p. 23, pl. 2, fig. 3,7 .

Very typical species, completely pyramidal, and without a differentiated final part. $V$. triangularis d'Orbigny differs from $V$. limbata in its more flaring final part of the test and raised sutures of the younger stage. Its occurrence is slightly more frequent than $V$. angulosa but rarer than $V$. aff. angulosa and $V$. aff. limbata.

\section{Valvulina sp. aff. V. limbata Terquem, 1882}

$$
\text { (Plate 1, Figures 1, 4) }
$$

This species is very common in the lower part of the cored interval. It differs from $V$. limbata by having one or two chambers on top of the completely triserial part.

\section{Genus CLAVULINA d'Orbigny, 1826}

Clavulina columnatortilis (d'Orbigny), 1826 (Plate 1, Figures 6, 11)

Valvulina columnatortilis d Orbigny, 1826, p. 270.

Clavulina auriculostoma Y. Le Calvez, 1952, p. 16, pl. 1, fig. 8.

Clavulina columnatortilis (d'Orbigny), Y. Le Calvez, 1970, p. 20, pl. 1, fig. 2, 7. Ferrer et al., 1973, p. 26, pl. 1, fig. 5; pl. 7, fig. 4.

C. columnatortilis is a very characteristic species in which the uniserial part is formed by more or less inflated chambers which are twisted from left to right. $C$. columnatortilis is frequently found in early and middle Eocene sediments of western Europe.

\section{Genus NODOSARIA Lamarck, 1812}

Nodosaria ef. parexilis Cushman and K.C. Stewart, 1930 (Plate 2, Figures 8, 9)

Nodosaria parexilis Cushman and K.C. Stewart, 1930, p. 55, pl. 2, fig. 13-15. Cushman and Parker, 1931, p. 6, pl. 1, fig. 15. Fairchild et al., 1969 , p. 37 , pl. 4 , fig. 18.

Extremely variable species quite common and characterized by its elongate and smooth chambers. The length of the chambers has a wide range and the initial chamber has an occasional spine.

\section{Genus FISSURINA Reuss, 1850}

Fissurina sp.

Few specimens of a smooth, rather large $(2.0 \mathrm{~mm})$ Fissurina, with a pronounced neck were found in these sediments.

\section{Genus BULIMINA d'Orbigny, 1826}

Bulimina bradburyi Martin, 1943

(Plate 2, Figures 7, 10)

Bulimina bradburyi Martin, 1943, p. 109, 110, pl. 6, fig. 4.
Only a few specimens of this species are found in the first two cores. They differ slightly from the figures of Martin in their longer initial triserial part and higher last chamber, but possess the very characteristic wide, comma-shaped aperture and its subrounded crosssection.

\section{Genus DISCORBIS Lamarck, 1804 \\ Discorbis perovalis (Terquem), 1882}

(Plate 2, Figures 1-3)

Rotalina perovalis Terquem, 1882 , p. 70 , pl. 6 , fig. 5 .

Discorbis perovalis (Terquem), Y. Le Calvez, 1970, p. 136, fig. 45.

Ferrer et al., 1973, p. 38-39, pl. 1, fig. 12-14; pl. 8, fig. 4-6.

This is the most abundant species of the cored intervals. As mentioned by Ferrer et al. (1973), its generic attribution is somewhat uncertain, but the specimens studied correspond to the species described by Terquem.

\section{Discorbis sp. cf. D. perovalis (Terquem), 1882}

This species is less abundant than $D$. perovalis. It differs from the typical $D$. perovalis in its less-pronounced button on the ventral side and less-elevated dorsal side. Since all transitions are found between the two populations, I think that it is just a geographical variety of $D$. perovalis.

\section{Discorbis? sp. \\ (Plate 2, Figures 4-6)}

This species is abundant in the lower part of the cored section. It is characterized by the rather inflated chambers and well-developed sutural slits. Since in many specimens there is a closed umbilicus, I think that the species belongs to the genus Discorbis. However, other specimens have a clearly open umbilicus, which makes it uncertain whether or not this species belongs to Discorbis or to Rosalina.

\section{Genus VALVULINERIA Cushman, 1926}

Valvulineria scrobiculata (Schwager), 1883

(Plate 3, Figures 1-3)

Anomalina scrobiculata Schwager, 1883, p. 129, pl. 29 (6), fig. 18a-d. Valvulineria scrobiculata (Schwager), Cushman and Ponton, 1932, p. 70 , fig. 5a-c. Mallory, 1959, p. 232, pl. 20, fig. 6.

Very well-preserved specimens of this species are very abundant throughout the cored intervals. They correspond to the figures and description of the American authors.

\section{Genus GLABRATELLA Dorreen, 1948 Glabratella sp. \\ (Plate 3, Figures 7-9)}

This is a large Glabratella (average diameter $0.3 \mathrm{~mm}$ ) with a low trochospiral (average $0.17 \mathrm{~mm}$ ) and the ventral side covered with ridges extending from the umbilicus to the periphery. The chambers are broad and moderately perforated and the sutures are straight and depressed. There are five chambers in the last whorl.

This species resembles $G$. herouvalensis (Le Calvez, 1954), but differs in its more flattened dorsal side and different ornamentation on the ventral side. It is also much bigger than the French species. It is common in the middle part of Core 2.

\section{Genus PATELLINA Williamson, 1858}

Patellina sp. cf. P. corrugata Williamson, 1858

Patellina corrugata Williamson, 1858, p. 46, pl. 3, fig. 86-89. Murray, 1971 , p. 147 , pl. 1, fig. $2-5$.

Only one very small specimen of a Patellina sp. was found near the top of Core 2 . It is attributed here to $P$. corrugata because it looks like the species described by Williamson, differing only in its very small size.

\section{Genus PARAROTALIA Le Calvez, 1949 \\ Pararotalia debourlei Le Calvez, 1970 \\ (Plate 3, Figures 4-6)}

Rotalia serrata Sacal and Debourle (non Ten Dam and Reinhold), 1957 , p. 40 , pl. 16, fig. 9-11.

Pararotalia debourlei Y. Le Calvez, 1970, p. 163, pl. 35, fig. 3, 6. 
This species is very abundant throughout the sediments studied. The species is easily recognized by its spiny periphery, high ventral chambers, and its pustulate dorsal side. Cibicides kernensis Cook, figured by Mallory, 1959, looks similar to $P$. debourlei but differs in its less-elevated ventral side.

\section{Genus CIBICIDES de Montfort, 1808}

Cibicides sp. ex gr. C. lobatulus (Walker and Jacob), 1798 (Plate 4, Figures 4-6)

Nautilus lobatulus Walker and Jacob, 1798, p. 642, pl. 14, fig. 36 . Cibicides lobatulus (Walker and Jacob), Kaasschieter, 1961, p. 221, pl.

14, fig. 5. Ferrer et al., 1973, p. 56, fig. 17 (4).

The high degree of variability of this species justifies the ex gr. I consider this group as characterized by more or less flattened specimens, with quite lobate final chambers and a fine keel. This species is quite common in the material studied.

\section{Cibicides sp.}

\section{(Plate 4, Figures 1-3)}

This large Cibicides is characterized by its coarsely perforated surface on both sides and a very distinct nonperforated keel. Generally the forms are elongated (Plate 4, Figures 1 and 2) but they can be more rounded (Plate 4, Figure 3 ). They are rather thin and the periphery is lobulated. The sutures are faintly depressed and the aperture at the base of the last chamber extends to the dorsal side.

None of the species of Cibicides known by me corresponds to these forms. However, additional investigations are necessary before erecting a new species especially in this highly variable genus.

\section{Genus VIRGULINA d'Orbigny, 1826}

Virgulina sp. aff. V. dibollensis Cushman and Applin, 1926 (Plate 6, Figures 9-11)

Virgulina dibollensis Cushman and Applin, 1926, p. 168, pl. 7, fig. 7. Mallory, 1959, p. 198, pl. 40, fig. 12.

This species is very common in the sediments studied. It is a very variable species (see Plate 6). Some specimens are very elongated, others much shorter and stout, and yet others at all intermediate stages between the two. All are characterized by a coarsely perforated wall, a large comma-shaped aperture, and broad and low chambers.

\section{Genus HETEROLEPA Franzenau, 1884}

Heterolepa sp. aff. H. pseudoungeriana (Cushman), 1922 (Plate 4, Figures 7-9)

Cibicides pseudoungeriana Cushman, 1922, p. 97, pl. 20, fig. 9.

Cibicides pseudoungerianus (Cushman), Bandy, 1949, p. 108, pl. 9, fig. 7.

Cibicides aff. C. pseudoungerianus (Cushman), Fairchild et al., 1969, p. 66 , pl. 20, fig. 1, 5, 6 .

These specimens are very similar to the ones figured by Fairchild et al. (1969). It is one of the most constant and abundant benthonic species found in the Eocene cores of Site 308.

\section{Genus LAMARCKINA Berthelin, 1881 \\ Lamarckina ovula Le Calvez, 1949 \\ (Plate 5, Figures 8, 9, 11)}

Lamarckina ovula Y. Le Calvez, 1949, p. 26, fig. 84-86. Y. Le Calvez, 1970 , p. 204, pl. 37, fig. 2, 3.

This characteristic species is common in the upper part of the cored interval, but is extremely rare at the bottom. The specimens correspond to the description and figures given by $\mathrm{Y}$. Le Calvez.

\section{Lamarckina rugulosa Plummer, 1926 \\ (Plate 5, Figures 7, 10, 12-15)}

Lamarckina rugulosa Plummer, 1926, p. 140, pl. 9, fig. 3. Mallory, 1959 , p. 229 , pl. 19 , fig. 18

This species is very abundant at the top of the cored interval. I have observed a high variation in the pustulose aspect of the dorsal side, from highly pustulose (Plate 5, Figures 10 and 15) to practically smooth (Plate 5, Figures 7 and 14). All other features correspond to the original description of Plummer (1926) and the figures of Mallory (1959).

\section{Genus STOMATORBINA Dorreen, 1948}

Stomatorbina torrei (Cushman and Bermudez), 1937

(Plate 5, Figures 1-6)

Lamarckina torrei Cushman and Bermudez, 1937, p. 21, pl. 2, fig. 2426.

Stomatorbina torrei (Cushman and Bermudez), Ferrer, 1971, p. 62, pl.

8, fig. 1, 2. Ferrer et al., 1973, p. 69, 70, pl. 2, fig. 3, 4; pl. 12, fig. 2, $3,5,6$.

The genus Stomatorbina was established by Dorreen (1948) on material of late Eocene age from New Zealand. Therefore it is not surprising to find representatives of this genus in the sediments studied here. The specimens found at Site 308 are very similar to the ones described from Cuba, New Zealand, and Spain. However, they differ slightly in the lower final chambers and less-marked supplementary apertures, which are represented by bands of clear shell material. The supplementary aperture is often absent in the last chamber (Plate 5, Figure 4).

Stomatorbina torrei (Cushman and Bermudez) is abundant in the lower part of the cored interval.

\section{INCERTAE SEDIS}

Genus REMANELLINA Tappan and Loeblich, 1968

Remanellina sp.

(Plate 6, Figures 1-8, 12)

Although the genus Remanellina was described by Tappan and Loeblich (1968) as belonging to the superfamily Codonellidea of the order Tintinnida, I do not think it represents a tintinnid. During the last 5 years, several papers (Keij, 1969, 1971; Willems, 1973a, 1973b) containing studies of different groups of these microfossils have been published. However none of the authors have clearly discussed their phylogeny and identification but accepted Tappan and Loeblich's interpretation. Until more is known on the morphology and shapes of the various groups of these microfossils, I prefer to consider them Incertae Sedis.

The specimens found in the deposits studied are cup-shaped to conical, with their greatest diameter near the middle part of the test. The collar is very clear in most of the specimens, but it differs from the only species described ( $R$. eocenica Tappan and Loeblich, 1968) in being flaired and not parallel sided. The aboral end of the test is rounded, and terminates in a short eccentric perforated horn. The exterior wall is lightly roughened and the interior surface is smoothly finished. The oral opening is restricted by a circumoral shelf which is generally relatively wide (Plate 6, Figures 5,6), but in certain cases quite narrow (Plate 6, Figure 6). Exceptionally, the collar is completely lacking (Plate 6, Figure 12). This species is placed tentatively in the genus Remaniella, but its intermediate nature between Remaniella and Tytthocorys (Tappan and Loeblich, 1968) deserves further study. The species is common in the upper part of the cored interval.

\section{ACKNOWLEDGMENTS}

The samples from Site 308 were made available by $\mathrm{H}$. P. Luterbacher. Esso Production Research-European provided part of the time and assistance needed to complete this report.

Help and advice was also received from Y. Le Calvez, R. Lehmann, J. P. Colin, T. Freudenthal, M. Pons, M. Hamaoui, and H. J. Oertli. M. A. Furrer reviewed the manuscript.

The scanning electron microphotographs were taken by $\mathrm{F}$. Saffon.

\section{REFERENCES}

Bandy, O. L., 1949. Eocene and Oligocene foraminifera from Little Stave Creek, Clarke County, Alabama: Am. Pal. Bull., v. 32, 210 p.

Cushman, J. A. and Applin, E. R., 1926. Texas Jackson foraminifera: Am. Assoc. Petrol. Geol., Bull., v. 10, p. 154189.

Cushman, J. A. and Bermudez, P. J., 1937. Further new species of foraminifera from the Eocene of Cuba: Cushman Lab. Foram. Res. Contrib., v. 13, pt. 1, p. 1-29. 
Cushman, J. A. and Parker, F. L., 1931. Miocene Foraminifera from the Temblor of the east side of the San Joaquin Valley, California: Cushman Lab. Foram. Res. Contrib., v. 7, pt. 1, p. 1-16.

Cushman, J. A. and Ponton, G. M., 1932. An Eocene foraminiferal fauna of Wilcox age from Alabama: Cushman Lab. Foram. Res. Contrib., v. 8, pt. 3, p. 51-72.

Cushman, J. A., Stewart, R. E., and Stewart, K. C., 1930. Tertiary foraminifera from Humboldt County, California: San Diego Soc. Nat. Hist. Trans., v. 6, p. 41-94.

Dorreen, J. M., 1948. A foraminiferal fauna from the Kaiatan Stage (upper Eocene) of New Zealand: J. Paleontol., v. 22, p. 281-300.

Fairchild, W. W., Wesendunk, P. R., and Weaver, D. W., 1969. Eocene and Oligocene foraminifera from the Santa Cruz Mountains, California: Univ. Calif. Publ. Geol. Sci., v. 81,93 p.

Ferrer, J., 1971. El Paleoceno y Eoceno del borde sur-oriental de la depresión del Ebro (Cataluña): Mem Suisses Pal., v. $90,70 \mathrm{p}$.

Ferrer, J., Le Calvez, Y., Luterbacher, H., and Premoli Silva, I., 1973. Contribution à l'étude des foraminiferes ilerdiens de la région de Tremp (Catalogne): Mém. Mus. Hist. Nat., sér. C, t. 29, 107 p.

Galloway, J. J. and Morrey, M., 1929. A lower Tertiary foraminiferal fauna from Manta, Ecuador: Am. Paleontol. Bull., v. 15 , p. $1-56$

Hazel, J. E. and Holden, J. C., 1971. Ostracoda of late Eocene age from Eua, Tonga: U.S. Geol. Surv. Prof. Paper 640-D.

Kaasschieter, J. P. H., 1961. Foraminifera of the Eocene of Belgium: Inst. R. Sci. Nat. Belgique, Mem. 147, 271 p.

Keij, A. J., 1969. Problematic calcareous microfossils from the Eocene of Belgium: Koninkl. Nederl. Akad. Wetensch. Amsterdam, Proc. ser. B, v. 72, p. 4-13.

1971. Tytthocorys mexicana n. sp. (Tintinnida) from the middle Eocene of Mexico: Koninkl. Nederl. Akad. Wetensch. Amsterdam, Proc., ser. B, v. 74, p. $547-$ 552.

Le Calvez, Y., 1949. Révision des Foraminiferes Lutétiens du Bassin de Paris II. Rotalidae et familles affines: Mém. Carte Géol. France, 54 p.

1952. Révision des foraminiferes Lutétiens du

Bassin de Paris. IV. Valvulinidae, Peneroplidae, Ophthalmidiidae, Lagenidae: Mém. Carte Géol. France, 64 p.

1970. Contribution à l'étude des foraminiferes Paléogènes du Bassin de Paris: Cahiers Paléontol., 326 p.

Le Calvez, Y. and Feugueur, L., 1954. Les Foraminifères du "Niveau d'Hérouval" à Hérouval (Oise): Soc. Géol. France Bull., ser. 6, t. 3, p. 503-508.

Mallory, V. S., 1959. Lower Tertiary biostratigraphy of the California Coast Ranges: Am. Assoc. Petrol. Geol. Publ., $416 \mathrm{p}$.

Martin, L. T., 1943. Eocene foraminifera from the Type Lodo Formation, Fresno County, California: Stanford Univ. Publ., Univ. ser., Geol. Sci., v. 3, p. 93-125.
Murray, J. W., 1971. An atlas of British recent Foraminiferids: London (Heinemann Educat. Books), 244 p.

d'Orbigny, A., 1826. Tableau méthodique de la classe des Céphalopodes: Ann. Sci. Nat., ser. 1, v. 7, p. 245-314.

Plummer, H. J., 1926. Foraminifera of the Midway Formation in Texas: Univ. Texas Bull. 2644, p. 3-206.

Sacal, V. and Debourle, V., 1957. Foraminiferes d'Aquitaine. 2è partie: Peneroplidae à Victoriellidae: Mém. Soc. Géol. France, n.s., t. 36 , no. 1.

Schwager, C., 1883. Die Foraminiferen aus den Eocaen ablagerungen der Lybischen Wüste und Aegypteus: Palaeontogr., Cassel, Bd. 30 (Folge 3, Bd. 6), t. 1, p. 79-153.

Tappan, H. and Loeblich, A. R., Jr., 1968. Lorica composition of modern and fossil Tintinnida (Ciliate Protozoa), systematics, geologic distribution, and some new Tertiary taxa: J. Paleontol., v. 42, p. 1378-1394.

Terquem, O., 1882. Les foraminiferes de l'Eocène des environs de Paris. Mém. Soc. Géol. France, sér. 3, t. 2, p. 1-193.

Walker, G. and Jacob, E., 1798. In Kanmacher, F. (Ed.), Adam's essays on the microscope. 2 ed: London (Londres Dillon and Keating), 712 p.

Willems, W., 1973a. Conicarcella tongerenensis n. sp. de la localité type des Sables de Grimmertingen (Oligocène inférieur de la Belgique): Bull. Soc. Belge Geol., Paleontol. Hydrol., t. 81, p. 13-25. 1973b. Problematic microfossils from the Ypres formation of Belgium: Bull. Soc. Belge Geol., Paleontol. Hydrol., t. 81, p. 53-73.

Williamson, W. C., 1858. On the recent foraminifera of Great Britain: London Roy. Soc., 107 p.

\section{APPENDIX A \\ Remarks On Ostracodes From Site 308 \\ H. J. Oertli (SNPA, Pau)}

Cores 1 to 3, and particularly Samples 1, CC and 3, CC, yielded rich assemblages of ostracodes. Although they are numerically dominated by a large Bairdia sp., they contain several other species, mostly ornamented, and most of them with an eye spot. These faunas may represent neritic or even nearshore life conditions. Part of the species encountered are figured on Plates 7 and 8 . A detailed investigation has not yet been undertaken, which explains why the plate captions contain no generic and specific assignments.

Without being cospecific, these interesting assemblages resemble those described by Hazel and Holden (1971) from the late Eocene of Tonga, except for the fact that these authors found bathyal together with sublittoral species; however, the latter were considered to be allochthonous (site of deposition presumed to be bathyal, but very near to the coast). Apart from the Bairdias at Site 308 (Cores 1 to 3), which might point to a deeper deposition than neritic, species that would distinctly indicate a bathyal environment (like Bythocythere, Bythocytheremorpha, and others) were not found. Therefore, it is more probable, at least after a preliminary study of the material, that the environment of deposition was (inner?) neritic. 


\section{PLATE 1}

All figures $\times 50$

Figures 1,4 Valvulina sp. aff. V. limbata Terquem.

Figures 2, $8 \quad$ Valvulina angulosa Le Calvez.

Figures 3,9,10 Valvulina sp. aff. V. angulosa Le Calvez.

Figures 5,7 Valvulina limbata Terquem.

Figures 6,11 Clavulina columnatortilis (d'Orbigny). 
PLATE 1
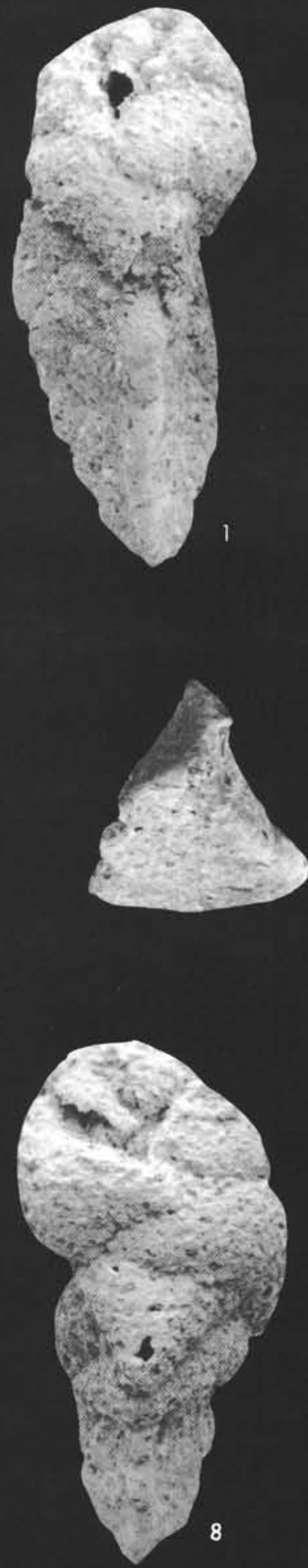
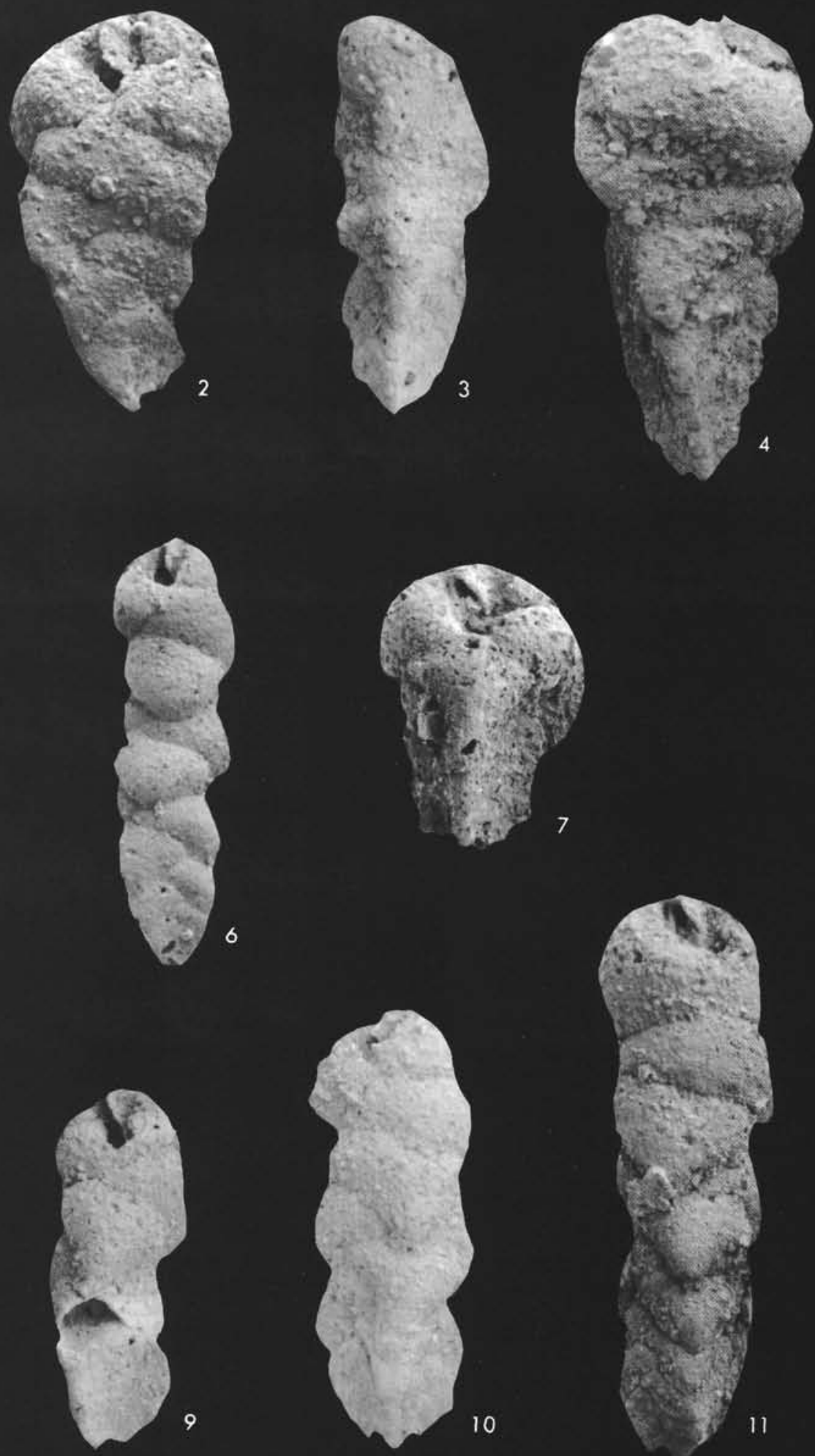
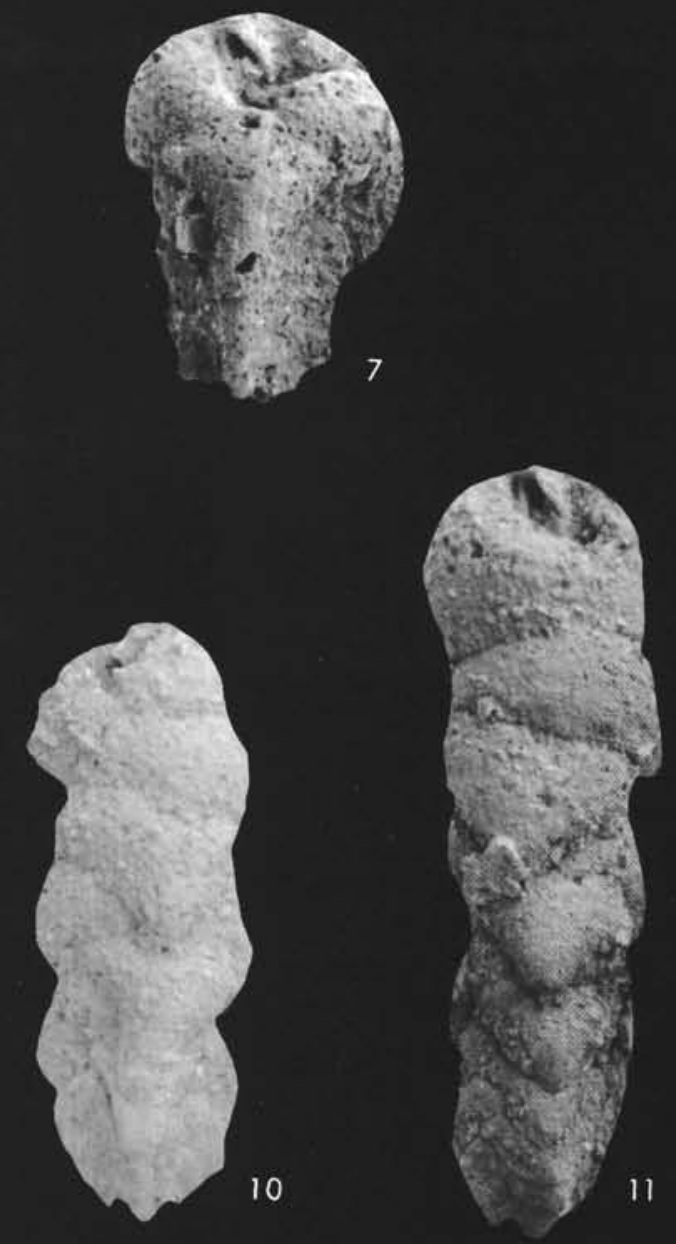


\section{PLATE 2}

Figures 1-3 Discorbis perovalis $($ Terquem). $\times 50$.

Figures 4-6 Discorbis? sp. $\times 100$.

Figures 7, $10 \quad$ Bulimina bradburyi Martin. $\times 50$.

Figures 8,9 Nodosaria sp. cf. N. parexilis Cushman and K.C. Stewart. $\times 50$. 

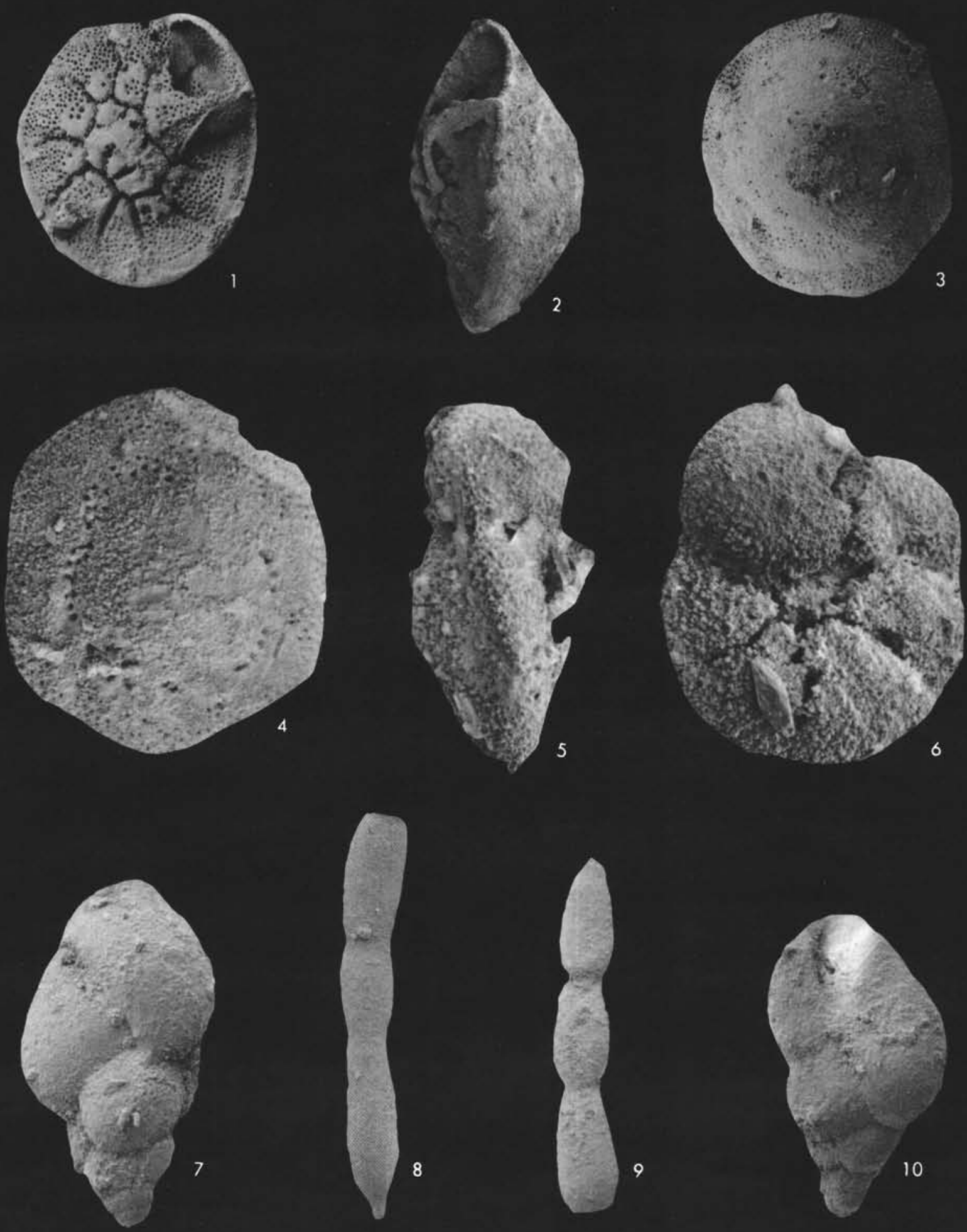
PLATE 3

Figures 1-3 Valvulineria scrobiculata (Schwager). $\times 100$.

Figures 4-6 Pararotalia debourlei Le Calvez. $\times 200$.

Figures 7-9 Glabratella $\mathrm{sp.} \times 200$. 


\section{PLATE 3}
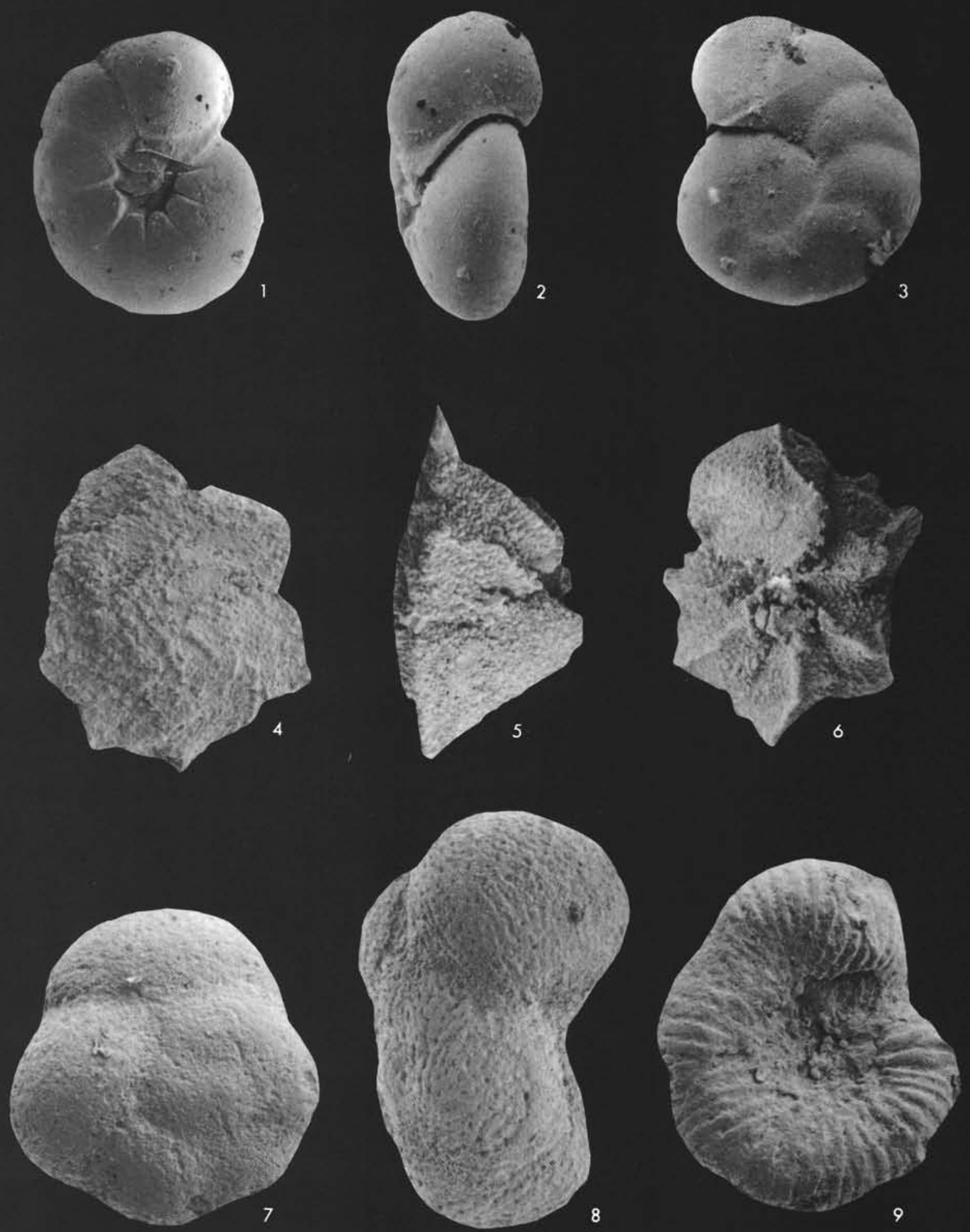


\section{PLATE 4}

Figures 1-3 Cibicides $\mathrm{sp} . \times 50$.

Figures 4-6 Cibicides ex gr. lobatulus (Walker and Jacob). $\times 100$.

Figures 7-9 Heterolepa sp. aff. H. pseudoungeriana (Cushman). $\times 100$. 

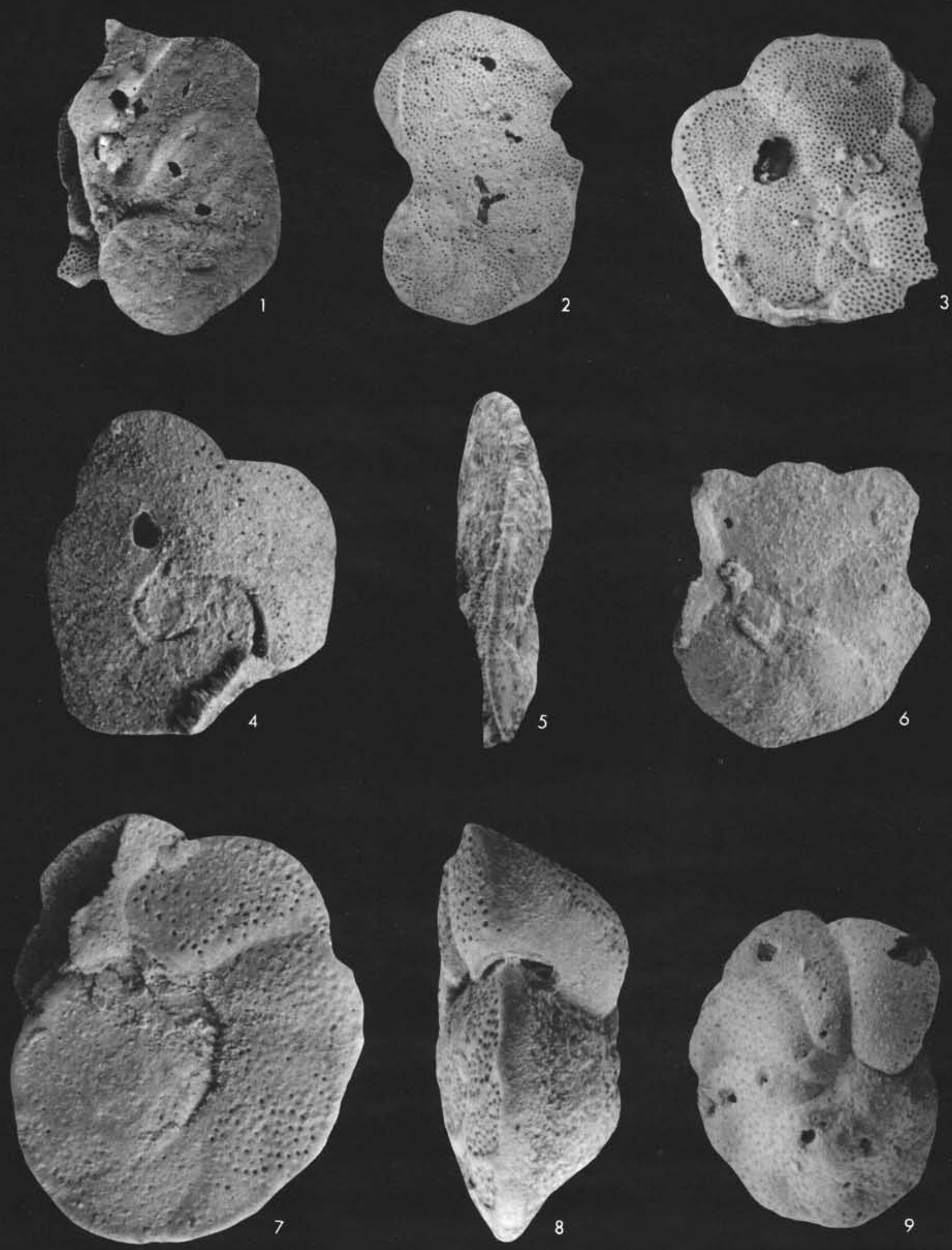


\section{PLATE 5}

Figures 1-6 Stomatorbina torrei (Cushman and Bermudez). $\times 100$.

Figures 7, 10, Lamarckina rugulosa Plummer. $\times 50$.

$12-15$

Figures 8, 9, 11 Lamarckina ovula Le Calvez. $\times 50$. 


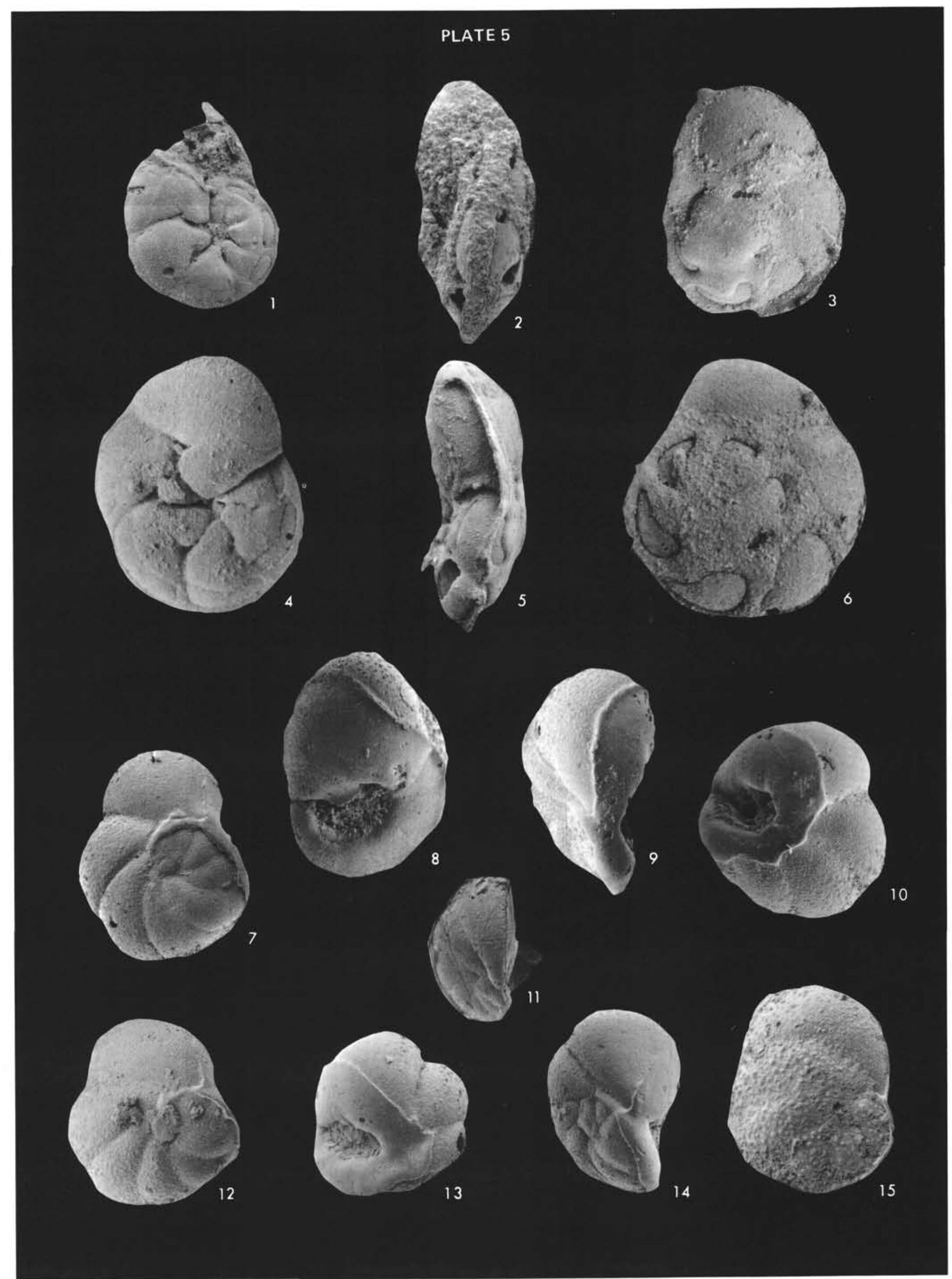




\section{PLATE 6}

Figures 1-8, 12 Remanellina sp.

$1,2,6$. Side view. The apical horn is generally eccentric (Figures 1, 6), but sometimes is almost in the center and perforated (Figure 2). $\times 200$.

3-5. Detail of the wall structure. The collar has the same acicular composition as the rest of the test. Figures 3 and 5, $\times 200$. Figure 4, detail of Figure 5, $\times 1000$.

7,12 . Oral view. Exceptionally, the collar is missing (Figure 12) but in general, all individuals possess a collar (Figure 7). $\times 200$.

8. Apical view. The asymmetrically placed horn is perforated but filled by foreign particles. Holes made by boring microorganisms are also visible (as in Figures 1, 3, and 7). $\times 200$.

Figures 9-11 Virgulina sp. aff. $V$. dibollensis Cushman and Applin. $\times 200$. 
PLATE 6
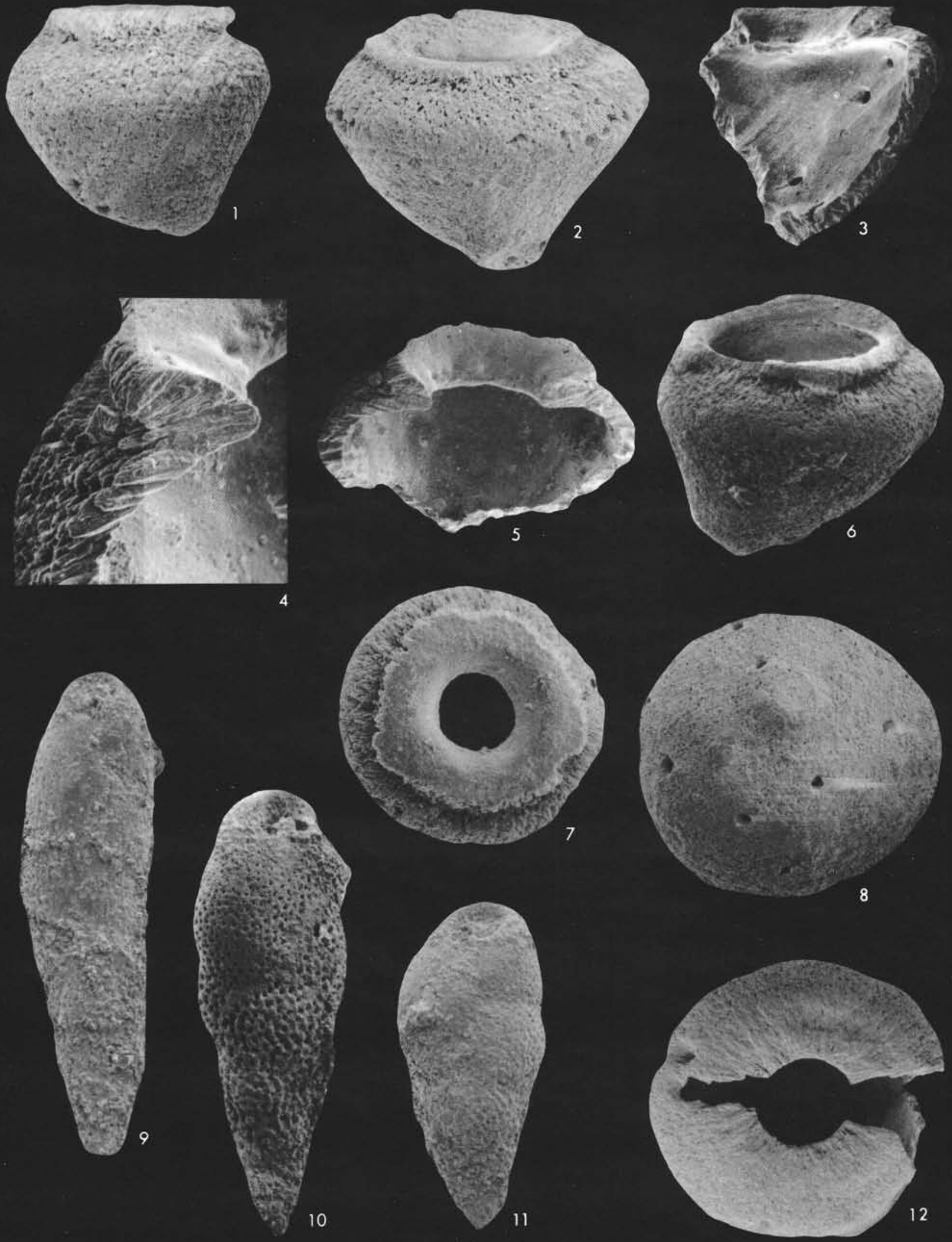


\section{PLATE 7}

Common ostracode species of Site 308, Cores 1 and 3. Magnification: all approximately $\times 80$

SEM photos by H. J. Oertli. - Ref.: SEM slide 58, film 74571 . 


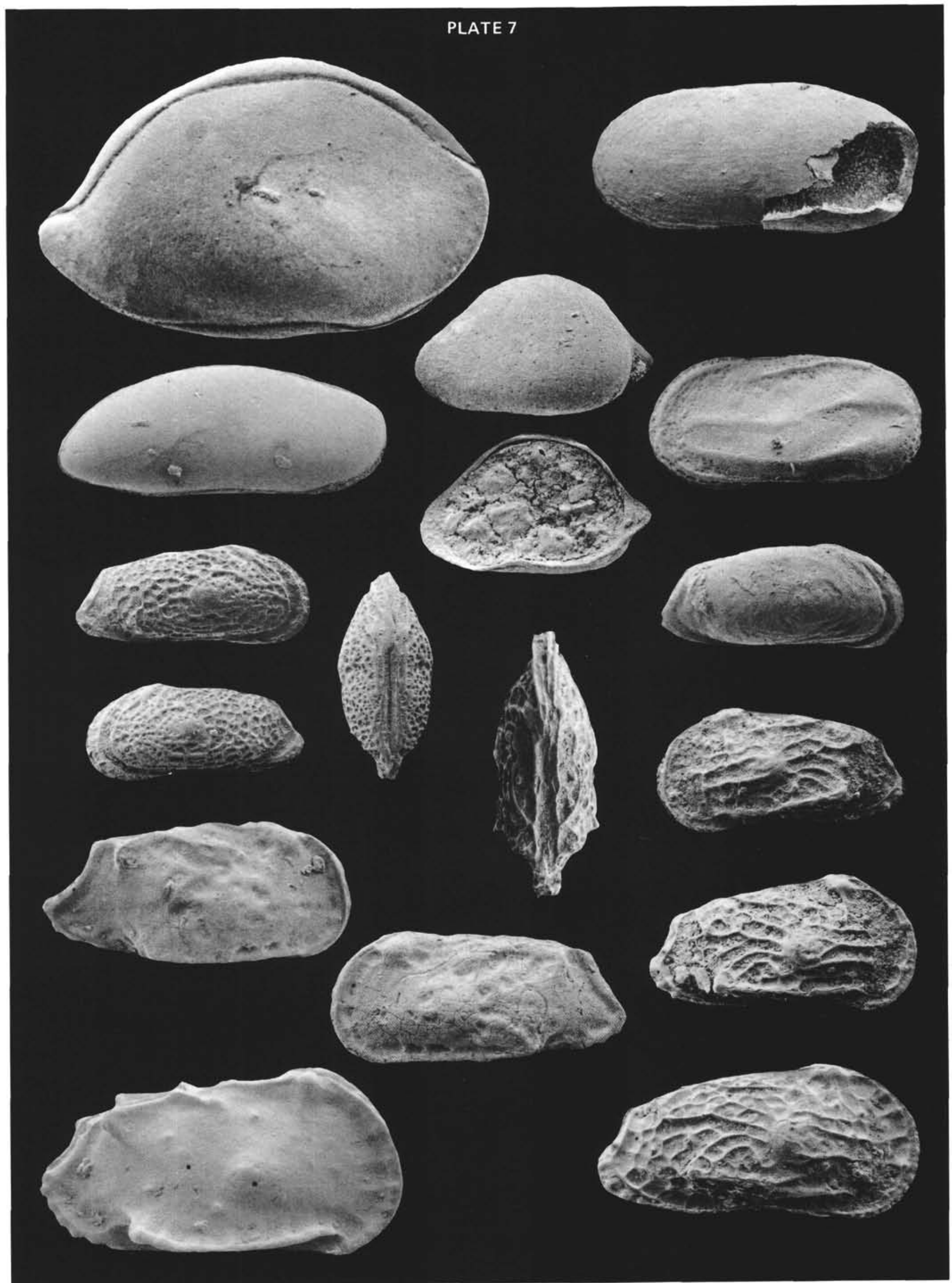


PLATE 8

Common ostracode species of Site 308, Cores 1 and 3.

Magnification: all approximately $\times 80$

SEM photos by H. J. Oertli. - Ref.: SEM slide 58, film 74571 . 


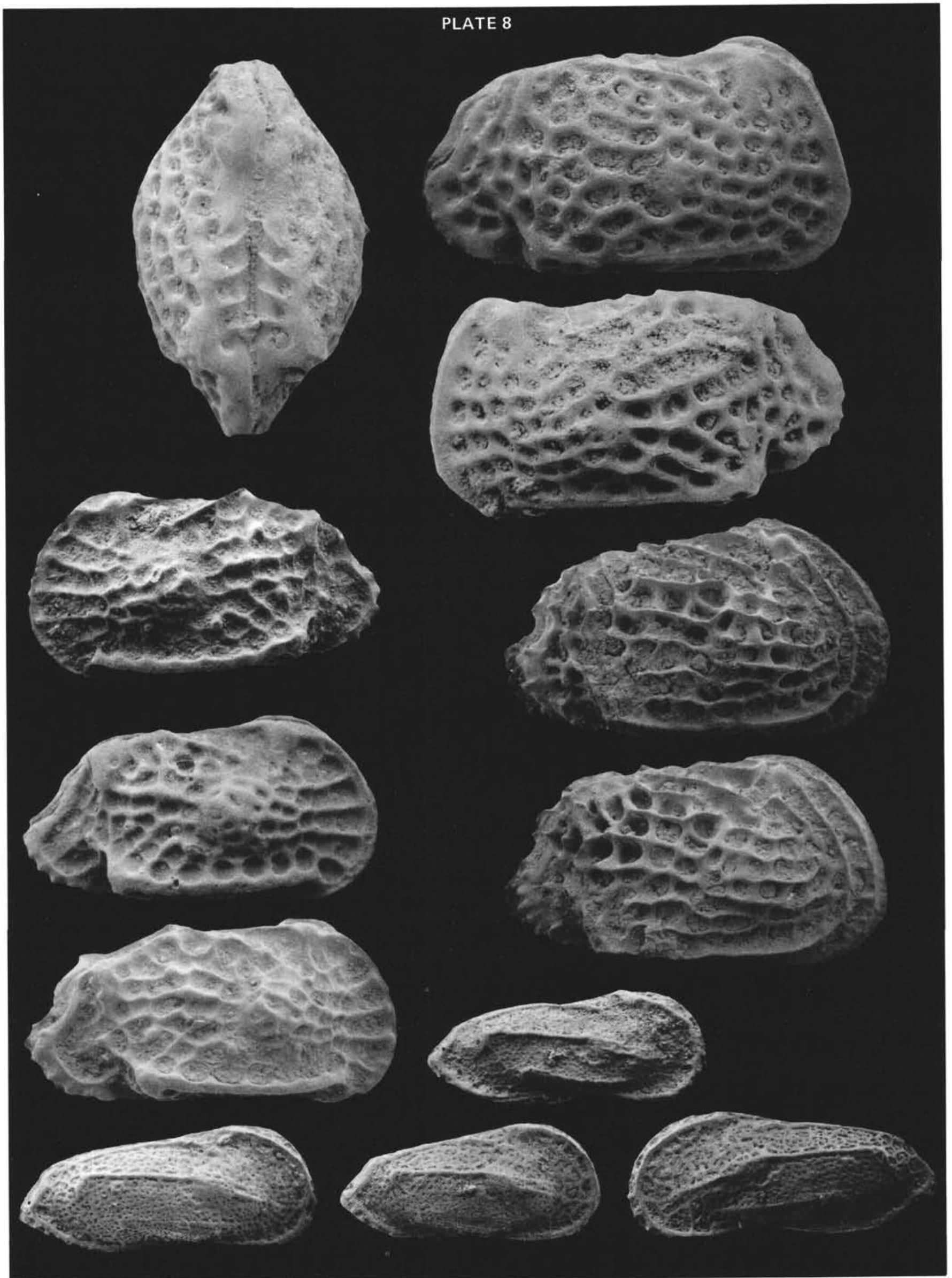

